\title{
Whether the Middle Eocene Salt-Forming Brine in the Kuqa Basin Reached the Potash-Forming Stage: Quantitative Evidence from Halite Fluid Inclusions
}

\author{
Yang Xu ${ }^{1},{ }^{1}$ Yangtong Cao, ${ }^{2}$ and Chenglin $\mathrm{Liu}^{2}$ \\ ${ }^{1}$ State Key Laboratory of Nuclear Resources and Environment, East China University of Technology, Nanchang 330013, China \\ ${ }^{2}$ MLR Key Laboratory of Metallogeny and Mineral Assessment, Institute of Mineral Resources, Chinese Academy of \\ Geological Sciences, Beijing 100037, China
}

Correspondence should be addressed to Yang Xu; geologyxu@163.com

Received 16 January 2021; Revised 23 February 2021; Accepted 4 March 2021; Published 10 March 2021

Academic Editor: Rongxi Li Copyright $\odot 2021$ Yang Xu et al. This is an open access article distributed under the Creative Commons Attribution License, which
permits unrestricted use, distribution, and reproduction in any medium, provided the original work is properly cited.

\begin{abstract}
The Kuqa Basin is an important potentially potash-bearing basin in China, and thick salt-bearing strata were deposited under the influence of multistage Tethyan transgression-regression cycles during the Eocene. At present, research on the process of potash formation in the Kuqa Basin has mostly focused on traditional salt mineralogy, whole-rock geochemistry, and evaporite sedimentary evolution characteristics. However, research on the original ore-forming parent fluid directly related to potash formation has not yet been carried out, directly hindering further evaluation of potash mineralization. Therefore, this paper takes the internal factors controlling potash formation as the starting point and analyzes the physical and chemical properties, such as the homogenization temperatures $\left(T_{\mathrm{h}}\right)$ and chemical compositions, of primary halite fluid inclusions. A total of $220 T_{\mathrm{h}}$ data from fluid inclusions were obtained, and the temperatures ranged from 9.4 to $54.1^{\circ} \mathrm{C}$, indicating a high-temperature brine environment conducive to the rapid deposition of the potash deposit. In total, 22 halite fluid inclusions were analyzed for chemical components. The highest $\mathrm{KCl}$ content reached $0.59 \%$, which was higher than the lowest industrial grade of potassiumrich brine $(0.5 \%)$, indicating that the brine experienced a high degree of evaporation and concentration during the salt-forming period and reached the potash precipitation stage. This paper provides quantitative data on the evolution of the sedimentary environment in the Kuqa Basin and supports future potash exploration.
\end{abstract}

\section{Introduction}

Global evaporites were concentrated in the Tethys region during the Mesozoic and Cenozoic, and in time and space, a series of evaporites and potash deposits developed sequentially from older in the west to younger in the east [1]. Although the Kuqa Basin, located on the northern branch of the eastern section of the Tethyan region, developed thick evaporite deposits in the Cenozoic, only some potassium minerals have been discovered to date and potash deposits with industrial mining value have not been found [2-4]. Liu et al. [5] proposed that the formation of potash deposits is the result of extremes in three coupled components: "climate, tectonics, and provenance". The Paleocene-Eocene thermal maximum (PETM) was the warmest global climate event in the Cenozoic, and this hightemperature event continued into the early Eocene, when temperatures began to slowly decrease until global warming occurred again in the middle Eocene climate optimum (MECO) [6-9]. There were favorable conditions for the formation of potash deposits in the Kuqa Basin during the Eocene, such as multistage provenance replenishment of Tethyan seawater and a relatively stable and enclosed tectonic structure [2, 10-12]. Many studies report that the Kuqa Basin has broad prospects for potash formation. However, the question of whether the Kuqa Basin reached the stage of potash precipitation currently remains controversial in the mineral deposit community. The most direct approach to answer this question is to determine the evolution stage of brine during the salt-forming period. 
Salt-forming brine is primary brine concentrated after the precipitation of rock salt, and it is an ore-forming fluid with a higher evaporation degree than that of rock salt. Restoring salt-forming brine evolution is a direct and reliable method to evaluate the potential for potash formation. Halite fluid inclusions are a good geological archive of brine during the salt-forming period and can provide quantitative and reliable data for studying the temperature, chemical composition, and evolution characteristics of paleobrine associated with potash mineralization. Fluid inclusions are undoubtedly an excellent geological thermometer. At present, scholars in China and other countries have conducted considerable research and widely discussed methods for measuring $T_{\mathrm{h}}$ in halite fluid inclusions and its representative geological significance. Roberts and Spence [13], Lowenstein et al. [14], Zambito and Benison [15], and Zhang et al. [16] conducted research on the $T_{\mathrm{h}}$ of single-phase liquid fluid inclusions in primary halite crystals made artificially in the laboratory and collected from ancient and modern salt lakes, and they showed that the measured $T_{\mathrm{h}}$ quantitatively represents the brine temperature and is close to the atmospheric temperature. Moreover, a high-temperature environment is conducive to shortening the time interval from brine concentration to potash precipitation; so, high-temperature brine can be used as an important indicator of potash formation. This situation is obviously manifested in the northern Shanxi Basin, Sichuan Basin, and Lanping-Simao Basin and the Sakon Nakhon Basin in Laos [17, 18]. Single-phase fluid inclusion components can reflect chemical information during brine evolution and have been widely used in many applications, such as the study of ancient seawater or lake water chemical evolution. Lowenstein et al. [19] used the chemical compositions of halite fluid inclusions for the first time to restore the variations in Phanerozoic seawater. In addition, halite fluid inclusions have been used to study the brine evolution process in salt-forming basins [20-23].

Therefore, this paper takes the internal factors controlling potash formation as the starting point and comprehensively analyzes the evolution stage of middle Eocene salt-forming brine in the Kuqa Basin by studying the evolution patterns of the temperatures and the chemical compositions of halite fluid inclusions. This paper uses halite fluid inclusions for the first time to quantitatively and directly reconstruct various ion concentrations in the middle Eocene salt-forming brine, which has great significance for potash exploration in the Kuqa Basin.

\section{Geological Setting}

The Tarim Basin experienced multiple marine transgressionregression cycles associated with the Tethys during the Late Cretaceous-Paleogene [24]. Seawater invaded the southwestern Tarim Basin through the Alay Valley in the Late Cretaceous. When the sea level rose in the early Paleocene, the Tethyan transgression range expanded and extended to the Kuqa Basin (Figure 1). At present, the timing of the final retreat of seawater from the Tarim Basin is considered to have occurred between 47 and $33 \mathrm{Ma}$ [24-27]. The key factor controlling the retreat was the northward spur of the Pamirs, not the collision between India and Eurasia [28-30]. The
Paleogene transgression-regression cycles in the Kuqa Basin were intermittent, and during each regression, sedimentation in the basin gradually transformed from marine deposits to continental deposits.

The Kuqa Basin is a secondary basin adjacent to the southern Tianshan Mountains in the northern part of the Tarim Basin, and it extends in a nearly east-west direction $[34,35]$ (Figure 2). The stable tectonic environment created favorable depositional conditions for the formation of the Paleogene evaporite series. The deposition center was located in the central and western parts of the basin, and huge thick salt-bearing strata formed. Paleocene and Eocene strata are composed of the Talak and Xiaokuzibai Formations of the Kumugeliemu Group. Marine fossils (such as foraminifera and gastropods) have been found at the bottom of the Talak Formation; the Xiaokuzibai Formation is composed of purple-red sandstone, silty mudstone, limestone, brown-red silty mudstone, and thick gypsum rock and rock salt deposits, and marine microfossils are found in the middle part [36]. Zheng and Meng [37] established the precise magnetostratigraphy of Paleogene strata in the Kuqa Basin based on paleomagnetic data and determined the ages of the top and bottom of the Kumgeliemu Group, which are $38 \mathrm{Ma}$ and $60.5 \mathrm{Ma}$, respectively. Teng et al. [38] and Li et al. [39] also proposed that the age of the boundary between the Paleogene Kumgeliemu Group and the Oligocene Suwei Formation is $38 \mathrm{Ma}$. Cao et al. [40] identified and compared Paleogene evaporite sedimentary cycles in the Kuqa Basin based on multiple drilling data from the Tarim Oilfield Company and developed a standard stratigraphic section of evaporite sedimentary cycles. Therefore, the formation age of salt-bearing strata from borehole DZK01 can be preliminarily determined to be middle Eocene.

\section{Materials and Experimental Procedure}

3.1. Materials. Rock salt samples used to measure $T_{\mathrm{h}}$ and the chemical compositions of fluid inclusions were collected from middle Eocene salt-bearing strata in borehole DZK01 (Figure 1). Borehole DZK01 is located in the northeastern Baicheng depression of the Kuqa Basin, and this is the first scientific research borehole in the basin to find potash deposits. The borehole mainly comprises mud-bearing rock salt, rock salt with gypsum and mud, gypsum-bearing argillaceous rock salt, and mud-bearing gypsiferous rock salt (Figures 3(a) and 3(b)).

Borehole samples were carefully selected, and the size, shape, and distribution characteristics of fluid inclusions were observed under a microscope and recorded to distinguish between primary and secondary fluid inclusions. Since halite with primary fluid inclusions is the most direct evidence to verify its originality, we placed selected primary halite samples into a desiccant for storage. Primary halite crystals are characterized by euhedral textures, and white smoky or cloudy, fluid inclusions are distributed along the growth surfaces of halite crystals in directional and regular strips. The sizes of individual inclusions vary, with diameters in the range of $\sim 3$ to $60 \mu \mathrm{m}$, and the inclusions are dominated by single-phase liquid inclusions, with few or no two-phase 


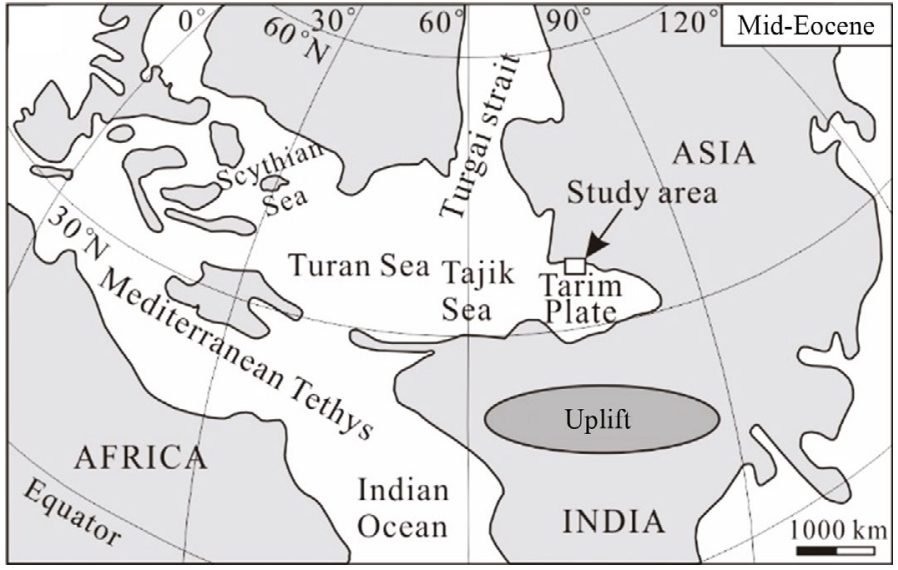

(a)

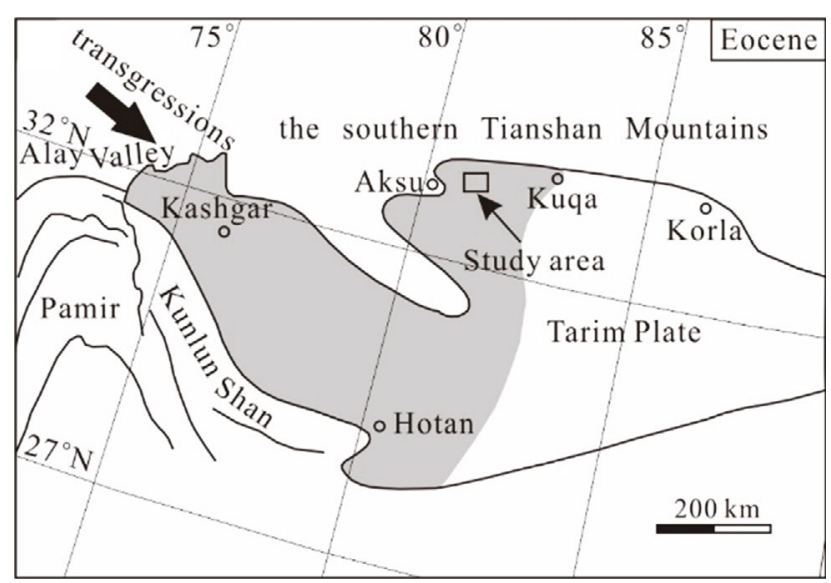

(b)

Figure 1: (a) Paleogeographic sketch map of the mid-Eocene in the Tethyan realm (modified from [31, 32]); (b) Eocene paleogeographic map of the Tarim Plate (modified from [33]).

gas-liquid or three-phase gas-liquid-solid inclusions containing daughter crystals.

3.2. Experimental Procedure. The $T_{\mathrm{h}}$ values of halite fluid inclusions were measured at the State Key Laboratory of Nuclear Resources and Environment, East China University of Technology. A Linkam THMS600 instrument (made in England) was used, and the measured temperature range was at -196 to $+600^{\circ} \mathrm{C}$. The accuracies of freezing and $T_{\mathrm{h}}$ data were $\pm 0.1^{\circ} \mathrm{C}$ and $\pm 0.5^{\circ} \mathrm{C}$, respectively. Before using cooling nucleation to measure $T_{\mathrm{h}}$, we used a small hammer to split halite crystals along their cleavage planes into approximately $1 \mathrm{~mm}$-thick slices. First, the halite cleavage slices were carefully observed under a microscope and photographs were taken to record all single-phase liquid fluid inclusions. Then, the selected cleavage slices were placed into a refrigerator (at $-15^{\circ} \mathrm{C}$ to $-20^{\circ} \mathrm{C}$ ) for one week and the slices were quickly moved from the refrigerator to a prepared heating and cooling stage and frozen at $-18^{\circ} \mathrm{C}$ until artificial nucleation bubbles appeared within the fluid inclusions. The initial heating rate was set to $0.5^{\circ} \mathrm{C} / \mathrm{min}$ and then slowed to $0.1^{\circ} \mathrm{C} / \mathrm{min}$ nearing $10^{\circ} \mathrm{C}$ until all observed artificial nucleation bubbles disappeared. Roberts and Spence [13] noted that the $T_{\mathrm{h}}$ of bubbles existing before cooling was abnormally high. Therefore, we chose fluid inclusions that featured artificial nucleation after cooling as the research subjects.

The determination of the chemical compositions of halite fluid inclusions was completed at the National Research Center for Geoanalysis. The laser ablation inductively coupled plasma mass spectrometry (LA-ICP-MS) method was used, and an Element 2 ICP mass spectrometer (Finnigan, Germany) and UP 213 laser (New Wave Company) were used. The diameter of the laser beam was $25 \mu \mathrm{m}$, the laser wavelength was $213 \mathrm{~nm}$, and the pulse duration was $4 \mathrm{~ns}$. Under laser ablation sampling conditions, high-purity helium gas was used as the carrier gas to optimize ablation and transmission efficiency. The actual energy acting on the samples was controlled between 0.03 and $0.06 \mathrm{~mJ}$ during the experiment, and the abla- tion energy density was controlled between 7 and $14 \mathrm{~J} / \mathrm{cm}^{2}$. Using the point ablation mode, the gas background acquisition time of each analysis point was approximately $15 \mathrm{~s}$, and the signal acquisition time was $45 \mathrm{~s}$. The calibration method involved internal standard-external standard combination methods $[42,43]$.

3.2.1. External Standard Method. The prepared standard solution was drawn into a pure quartz capillary tube and quickly sealed with epoxy resin. During the test and analysis, manufactured artificial fluid inclusions were attached to a glass sheet with double-sided adhesive and put into the laser ablation sample chamber together with test samples.

3.2.2. Internal Standard Method. $\mathrm{Na}$ was selected as the internal standard element for halite fluid inclusion samples, and the $\mathrm{Na}$ content was calculated to be at $141.62 \mathrm{~g} / \mathrm{L}$ based on the theoretical value. The relative sensitivity between the standard calibration instrument and elements in the unknown sample was assumed to remain unchanged, that is, calibration was carried out according to the consistency of changes in the internal standard element and the elements to be measured $[42,44]$.

Figures 3(c) and 3(d) show fluid inclusions after laser ablation. Figure 4 shows the variation curve of the mass spectrum signal intensity with time during the analysis of typical halite fluid inclusions. From 1 to $14 \mathrm{~s}$, the measured signal intensity is the background value; the signal intensities of the major elements $\mathrm{Na}, \mathrm{K}, \mathrm{Mg}$, and $\mathrm{Ca}$ are very stable, and the signal intensities of trace elements $\mathrm{Rb}, \mathrm{Sr}$, and B fluctuate slightly. At $15 \mathrm{~s}$, the signal intensities of $\mathrm{Na}, \mathrm{Mg}$, and $\mathrm{Sr}$ increase instantly and those of other elements remain stable; this is the result of laser ablation reaching the halite surface and releasing $\mathrm{Na}, \mathrm{Mg}$, and $\mathrm{Sr}$. Then, the signal intensity of $\mathrm{Na}$ decreases slightly and the signal intensities of the other elements decrease quickly to the initial background values. From 26 to $33 \mathrm{~s}$, when laser ablation reaches the fluid inclusion, the signal intensities of all major and trace elements increase significantly, especially $\mathrm{K}, \mathrm{Mg}, \mathrm{Ca}$, and $\mathrm{Sr}$. The signal 


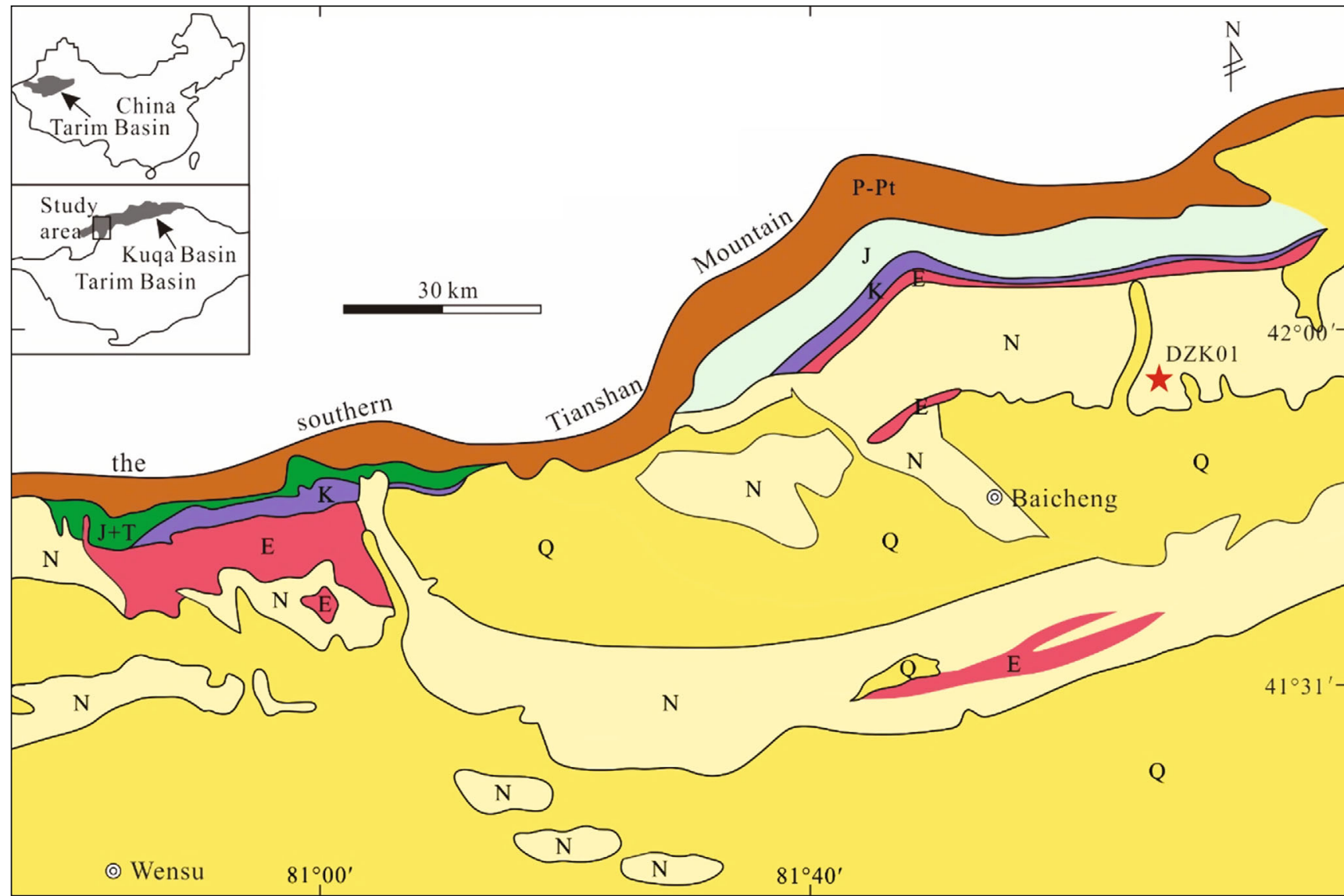

\begin{tabular}{|c|c|}
\hline $\mathrm{Q}$ & Quaternary \\
\hline $\mathrm{N}$ & Neogene \\
\hline $\mathrm{E}$ & Paleogene \\
\hline $\mathrm{K}$ & Cretaceous \\
\hline$\star$ & Borehole location \\
\hline
\end{tabular}

\begin{tabular}{|c|c|}
\hline J & Jurassic \\
\hline $\mathrm{J}+\mathrm{T}$ & $\begin{array}{l}\text { Jurassic } \\
\text { and Triassic }\end{array}$ \\
\hline $\mathrm{P}-\mathrm{Pt}$ & Paleozoic \\
\hline () & County \\
\hline
\end{tabular}

FIgURE 2: Simplified geological map of the Kuqa Basin [41].

intensities of these elements remain high for $7 \mathrm{~s}$, indicating that there is abundant fluid available for ablation and that the inclusion is large.

\section{Results}

Approximately 15\% of single-phase liquid fluid inclusions generated artificial nucleation vapor bubbles after cooling. In total, $220 T_{\mathrm{h}}$ values were measured from artificially nucleated vapor bubbles in primary halite crystals from borehole DZK01 (Table 1) and the $T_{\mathrm{h}}$ values of the four stratigraphic intervals range from 11.1 to $47.1^{\circ} \mathrm{C}(\mathrm{S} 4,1363 \mathrm{~m}), 13.2$ to $52.3^{\circ} \mathrm{C}(\mathrm{S} 3,1373 \mathrm{~m}), 15.3$ to $36.2^{\circ} \mathrm{C}(\mathrm{S} 2,1382 \mathrm{~m})$, and 9.4 to $54.1^{\circ} \mathrm{C}(\mathrm{S} 1,1470 \mathrm{~m})$. The corresponding average $T_{\mathrm{h}}$ values are $27.2^{\circ} \mathrm{C}, 31.2^{\circ} \mathrm{C}, 23.2^{\circ} \mathrm{C}$, and $30.5^{\circ} \mathrm{C}$. In this paper, each inclusion-rich band is regarded as an individual fluid inclusion assemblage (FIA) [46], showing that all primary fluid inclusions near the FIA formed almost simultaneously. The
$T_{\mathrm{h}}$ range within each FIA is within $15^{\circ} \mathrm{C}$, and $84 \%$ of FIAs have a range of less than $10^{\circ} \mathrm{C}$. The $T_{\mathrm{h}}$ range measured within all FIAs yields an average value of $8.0^{\circ} \mathrm{C}$, with a maximum value of $11.7^{\circ} \mathrm{C}$ and a minimum value of $4.6^{\circ} \mathrm{C}$.

The chemical compositions of 22 fluid inclusions from 10 rock salt samples were determined by LA-ICP-MS (Table 2), and their sizes ranged from $\sim 30 \times 20 \mu \mathrm{m}$ to $80 \times 30 \mu \mathrm{m}$. The chemical compositions of fluid inclusions in the same sample are quite different. Based on petrographic observations under the microscope, they come from different halite crystals in the same sample and information on paleobrine from different stages is captured during halite crystallization, such as the no. 18 and no. 19 fluid inclusions.

\section{Discussion}

5.1. Reliability and Stability of $T_{h}$ Data. Damage or recrystallization occurs easily during burial and at depth due to the 


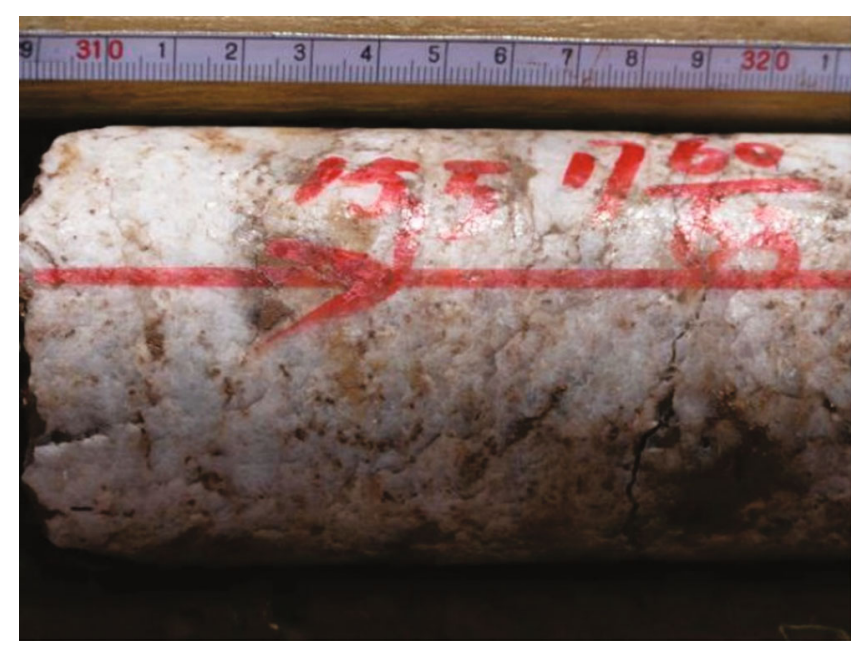

(a)

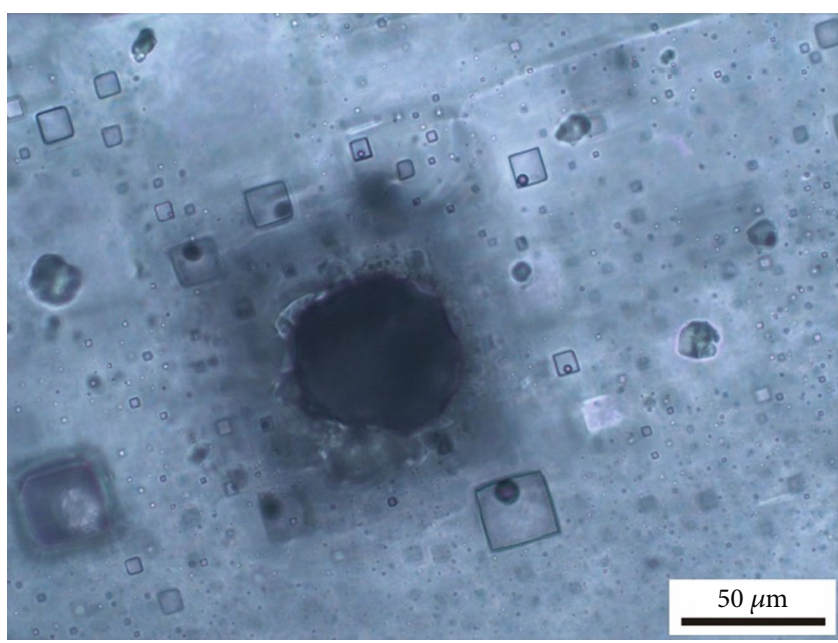

(c)

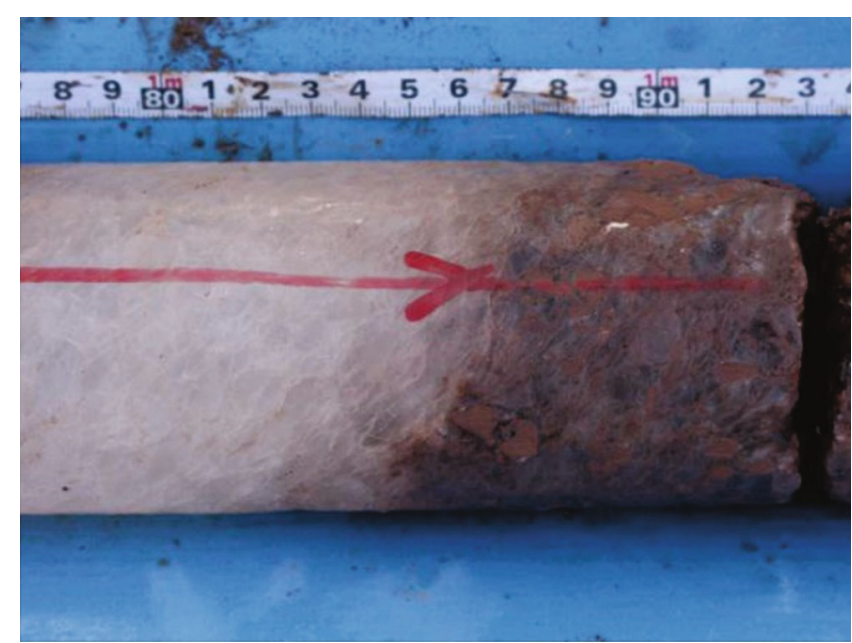

(b)

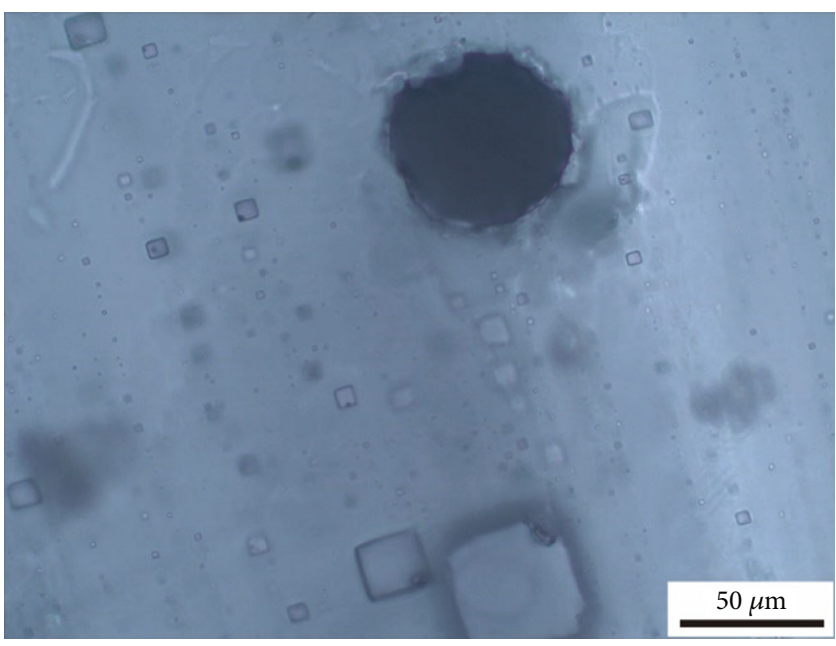

(d)

FIGURE 3: Characteristics of evaporite lithology and halite fluid inclusions from borehole DZK01 in the Kuqa Basin. (a) Gypsum rock with maroon boulder clay; (b) pure rock salt and rock salt with maroon boulder clay; (c, d) primary band-like fluid inclusions developed along growth faces of halite crystals and pits left on the surface of halite after laser ablation.

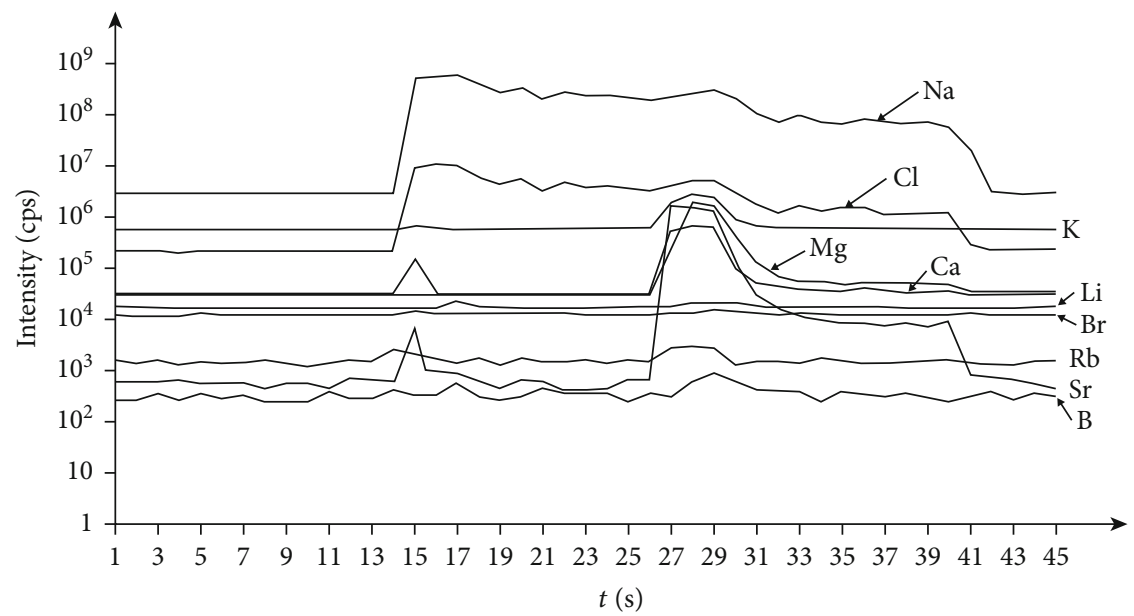

FIgURE 4: Mass spectral signal intensity versus time for a single fluid inclusion in halite (no. 4 fluid inclusion from $1385 \mathrm{~m}$ ). 
TABLE 1: $T_{\mathrm{h}}\left({ }^{\circ} \mathrm{C}\right)$ of middle Eocene halite primary fluid inclusions in borehole DZK01, Kuqa Basin.

\begin{tabular}{|c|c|c|c|c|c|c|}
\hline Sample & $\begin{array}{l}\text { Depth } \\
(\mathrm{m})\end{array}$ & $T_{\mathrm{h}}\left({ }^{\circ} \mathrm{C}\right) / \operatorname{size}(\mu \mathrm{m})$ & $\begin{array}{c}T_{\text {hMAX }} \\
\left({ }^{\circ} \mathrm{C}\right)\end{array}$ & $\begin{array}{c}T_{\mathrm{hMIN}} \\
\left({ }^{\circ} \mathrm{C}\right)\end{array}$ & $\begin{array}{c}T_{\mathrm{hAVG}} \\
\left({ }^{\circ} \mathrm{C}\right)\end{array}$ & $\begin{array}{c}T_{\text {hRANGE }} \\
\left({ }^{\circ} \mathrm{C}\right)\end{array}$ \\
\hline \multirow[t]{7}{*}{ S1 } & 1363 & & 47.1 & 11.1 & 27.2 & \\
\hline & FIA 1 & $11.1 / 16 ; 13.8 / 15 ; 14.1 / 29 ; 16.4 / 28 ; 17.2 / 28 ; 17.8 / 24 ; 18.1 / 20 ; 18.8 / 22$ & & & & 7.7 \\
\hline & FIA 2 & $\begin{array}{c}19.5 / 22 ; 20.1 / 26 ; 20.5 / 18 ; 20.8 / 8 ; 21.3 / 12 ; 21.5 / 13 ; 22.2 / 15 ; 22.4 / 36 ; 22.6 / 42 ; 23.8 / 8 ; \\
24.1 / 6 ; 24.1 / 29 ; 24.2 / 28 ; 24.9 / 15 ; 25.1 / 19\end{array}$ & & & & 5.6 \\
\hline & FIA 3 & $22.8 / 19 ; 23.7 / 10 ; 24.4 / 32 ; 24.6 / 16 ; 24.7 / 25 ; 28.3 / 22 ; 28.4 / 19 ; 28.5 / 28 ; 28.6 / 31 ; 28.7 / 30$ & & & & 5.9 \\
\hline & FIA 4 & $25.6 / 18 ; 26.3 / 33 ; 26.5 / 34 ; 26.7 / 20 ; 29.2 / 31 ; 30.2 / 21 ; 30.2 / 28 ; 30.3 / 20 ; 31.3 / 18$ & & & & 5.7 \\
\hline & FIA 5 & $\begin{array}{c}30.8 / 16 ; 31.2 / 16 ; 31.5 / 17 ; 31.5 / 15 ; 31.6 / 19 ; 31.7 / 25 ; 31.7 / 15 ; 32.3 / 10 ; 33.2 / 18 ; 33.6 / 14 ; \\
33.8 / 10 ; 35.4 / 26\end{array}$ & & & & 4.6 \\
\hline & FIA 6 & $37.2 / 10 ; 37.3 / 11 ; 39.9 / 16 ; 41.6 / 15 ; 42.7 / 23 ; 44.8 / 29 ; 47.1 / 18$ & & & & 9.9 \\
\hline \multirow[t]{6}{*}{ S2 } & 1373 & & 52.3 & 13.2 & 31.2 & \\
\hline & FIA 1 & $13.2 / 27 ; 14.5 / 26 ; 14.6 / 23 ; 15.1 / 20 ; 15.5 / 19 ; 19.5 / 14 ; 21.2 / 34 ; 22.1 / 38$ & & & & 8.9 \\
\hline & FIA 2 & $20.8 / 18 ; 21.0 / 10 ; 23.4 / 41 ; 28.9 / 28 ; 29.5 / 27 ; 29.6 / 24 ; 29.6 / 23$ & & & & 8.8 \\
\hline & FIA 3 & $29.1 / 16 ; 29.8 / 25 ; 34.1 / 28 ; 34.2 / 12 ; 34.5 / 13 ; 35.1 / 18 ; 35.2 / 16$ & & & & 6.1 \\
\hline & FIA 4 & $35.3 / 26 ; 38.1 / 28 ; 38.1 / 23 ; 38.4 / 16 ; 45.6 / 20$ & & & & 10.3 \\
\hline & FIA 5 & $42.6 / 14 ; 45.8 / 7 ; 46.4 / 22 ; 47.6 / 19 ; 49.2 / 15 ; 52.3 / 31$ & & & & 9.7 \\
\hline \multirow[t]{4}{*}{ S3 } & 1382 & & 36.2 & 15.3 & 23.2 & \\
\hline & FIA 1 & $\begin{array}{c}15.3 / 24 ; 16.3 / 10 ; 16.4 / 9 ; 16.4 / 35 ; 16.6 / 33 ; 16.7 / 24 ; 17.2 / 26 ; 17.5 / 23 ; 17.6 / 18 ; 17.8 / 14 \\
18.4 / 10 ; 18.8 / 27 ; 19.1 / 28 ; 19.3 / 28 ; 19.5 / 25 ; 19.6 / 17 ; 19.6 / 16 ; 19.8 / 27 ; 20.5 / 8 ; 20.8 / 11 \\
22.3 / 19 ; 22.8 / 24 ; 23.8 / 25\end{array}$ & & & & 8.5 \\
\hline & FIA 2 & $24.3 / 12 ; 24.3 / 18 ; 24.5 / 31 ; 24.8 / 48 ; 25.1 / 26 ; 26.1 / 27 ; 26.2 / 16 ; 27.3 / 29 ; 27.6 / 33 ; 31.4 / 15$ & & & & 7.1 \\
\hline & FIA 3 & $28.9 / 15 ; 31.2 / 14 ; 31.6 / 31 ; 31.6 / 32 ; 31.6 / 18 ; 32.7 / 26 ; 32.8 / 28 ; 36.2 / 20$ & & & & 7.3 \\
\hline \multirow[t]{6}{*}{ S4 } & 1470 & & 54.1 & 9.4 & 30.5 & \\
\hline & FIA 1 & $\begin{array}{c}9.4 / 24 ; 10.2 / 23 ; 14.5 / 25 ; 15.6 / 28 ; 15.7 / 12 ; 16.2 / 20 ; 16.3 / 28 ; 16.7 / 24 ; 17.3 / 33 ; 17.5 / 38 \\
17.8 / 36 ; 19.5 / 31 ; 20.7 / 46 ; 20.8 / 41 ; 21.1 / 27\end{array}$ & & & & 11.7 \\
\hline & FIA 2 & $\begin{array}{c}22.1 / 35 ; 22.2 / 24 ; 22.8 / 28 ; 23.1 / 24 ; 24.1 / 26 ; 24.3 / 15 ; 25.1 / 24 ; 25.9 / 16 ; 26.1 / 26 ; 26.2 / 17 \\
26.3 / 25 ; 26.5 / 26 ; 26.7 / 33 ; 27.2 / 37 ; 27.2 / 35 ; 27.8 / 26 ; 27.8 / 8 ; 28.1 / 8 ; 28.2 / 7 ; 28.5 / 24 \\
29.3 / 18 ; 29.3 / 23 ; 29.4 / 25 ; 30.1 / 29\end{array}$ & & & & 8.0 \\
\hline & FIA 3 & $\begin{array}{l}28.6 / 25 ; 28.9 / 15 ; 29.1 / 19 ; 30.2 / 38 ; 30.2 / 44 ; 30.3 / 35 ; 30.4 / 21 ; 30.5 / 20 ; 31.1 / 17 ; 31.7 / 22 \\
31.9 / 28 ; 32.4 / 23 ; 32.4 / 14 ; 32.5 / 15 ; 32.7 / 22 ; 32.8 / 10 ; 33.2 / 33 ; 34.5 / 29 ; 34.6 / 14 ; 35.4 / 41 \\
\quad 36.1 / 18 ; 36.4 / 22 ; 36.5 / 31 ; 36.6 / 27 ; 36.8 / 20 ; 37.6 / 31 ; 37.8 / 15 ; 38.1 / 24\end{array}$ & & & & 5.7 \\
\hline & FIA 4 & $\begin{array}{c}35.5 / 37 ; 35.6 / 34 ; 35.8 / 36 ; 38.4 / 16 ; 38.5 / 28 ; 40.8 / 24 ; 41.6 / 35 ; 41.8 / 10 ; 42.1 / 18 ; 44.8 / 27 ; \\
46.1 / 16 ; 46.1 / 28\end{array}$ & & & & 10.6 \\
\hline & FIA 5 & $44.5 / 20 ; 45.3 / 26 ; 46.4 / 24 ; 47.6 / 23 ; 52.4 / 20 ; 54.1 / 29$ & & & & 9.6 \\
\hline
\end{tabular}

$T_{\mathrm{hMAX}}$ : maximum homogenization temperature; $T_{\mathrm{hMIN}}$ : minimum homogenization temperature; $T_{\mathrm{hAVG}}$ : average homogenization temperature; $T_{\mathrm{hRANGE}}:$ range of $T_{\mathrm{h}}$ data; FIA: fluid inclusion assemblage.

deliquescent and solubility nature of rock salt and can affect the reliability and stability of $T_{\mathrm{h}}$ data, especially for ancient rock salt samples. The $T_{\mathrm{h}}$ data do not require pressure correction because rock salt forms in a shallow depositional environment and the temperatures captured by fluid inclusions under low-pressure conditions are approximately equal to $T_{\mathrm{h}}$, thus providing a direct record of temperature during rock salt deposition. Primary fluid inclusions from the same inclusion growth band were captured contemporaneously [45]. However, multiple inclusion bands in primary halite crystals were not formed contemporaneously. Therefore, $T_{\mathrm{h}}$ data obtained from different inclusion bands are also diverse [45].

We use two methods to verify whether primary fluid inclusions have undergone damage or alteration from thermal reequilibration: thermal reequilibration analysis of the
$T_{\mathrm{h}}$ data and evaluation of the relationship between the size and $T_{\mathrm{h}}$ of fluid inclusions. On the one hand, the consistency of the $T_{\mathrm{h}}$ data from individual FIAs can be used as an indicator for evaluating thermal reequilibration [45]. Goldstein and Reynolds [46] noted that approximately $90 \%$ of $T_{\mathrm{h}}$ data in individual FIAs have a fluctuation range of less than $15^{\circ} \mathrm{C}$, indicating that primary fluid inclusions have not undergone alteration from thermal reequilibration. The $T_{\mathrm{h}}$ data in this paper meet this criterion (Table 1), as the temperature ranges of all $T_{\mathrm{h}}$ data from 19 FIAs are less than $15^{\circ} \mathrm{C}$, with a minimum of $4.6^{\circ} \mathrm{C}$ and a maximum of $11.7^{\circ} \mathrm{C}$. Therefore, the halite crystals have not been affected by thermal reequilibration. Furthermore, the relationship between the size and $T_{\mathrm{h}}$ of fluid inclusions can be used as another indicator to determine whether fluid inclusions have been affected by thermal 
TABLE 2: Ion concentrations in halite fluid inclusions from borehole DZK01 in the Kuqa Basin.

\begin{tabular}{|c|c|c|c|c|c|c|c|c|c|}
\hline \multirow{2}{*}{ Depth (m) } & \multirow{2}{*}{ Inclusion no. } & \multicolumn{3}{|c|}{$\rho(\mathrm{B}) /(\mathrm{g} / \mathrm{L})$} & \multicolumn{5}{|c|}{$\rho(\mathrm{B}) /(\mathrm{mg} / \mathrm{L})$} \\
\hline & & $\mathrm{K}^{+}$ & $\mathrm{Ca}^{2+}$ & $\mathrm{Mg}^{2+}$ & $\mathrm{Li}^{+}$ & $\mathrm{B}^{+}$ & $\mathrm{Rb}^{+}$ & $\mathrm{Sr}^{2+}$ & $\mathrm{Br}^{-}$ \\
\hline 1370 & 1 & 0.23 & 1.16 & 0.42 & 0.12 & 1.62 & 0.44 & 23.52 & 12.64 \\
\hline 1373 & 2 & 0.11 & 4.21 & 0.19 & 0.86 & 2.60 & 0.00 & 138.08 & 12.56 \\
\hline 1374 & 3 & 0.12 & 0.17 & 0.13 & 0 & 0.98 & 0.07 & 4.74 & 2.55 \\
\hline 1385 & 4 & 0.47 & 0.06 & 0.09 & 0.05 & 0.75 & 0.31 & 0.80 & 5.08 \\
\hline 1415 & 5 & 0.26 & 3.09 & 0.53 & 1.80 & 1.18 & 0.15 & 115.89 & 10.33 \\
\hline \multirow{3}{*}{1435} & 6 & 1.25 & 0.06 & 0.06 & 0.55 & 1.76 & 3.35 & 0.66 & 15.25 \\
\hline & 7 & 0.30 & 0.04 & 0.03 & 1.23 & 0.52 & 1.94 & 0.54 & 6.41 \\
\hline & 8 & 0.28 & 0.02 & 0.02 & 0.44 & 0.16 & 0.38 & 0.11 & 3.11 \\
\hline \multirow{3}{*}{1436} & 9 & 0.27 & 0.02 & 0.01 & 0.06 & 0.07 & 0.26 & 0.16 & 6.06 \\
\hline & 10 & 0.12 & 0.22 & 0.08 & 0.52 & 0.18 & 0.06 & 7.56 & 3.35 \\
\hline & 11 & 0.07 & 0.05 & 0.05 & 0.27 & 0.19 & 0.13 & 0.94 & 4.72 \\
\hline \multirow{2}{*}{1469} & 12 & 0.34 & 0.35 & 0.16 & 0.40 & 0.27 & 0.09 & 7.56 & 2.83 \\
\hline & 13 & 0.10 & 0.65 & 0.10 & 0.04 & 0.12 & 0.05 & 17.39 & 3.65 \\
\hline \multirow{7}{*}{1476} & 14 & 0.12 & 0.23 & 0.01 & 0.01 & 0.44 & 0.08 & 0.10 & 18.00 \\
\hline & 15 & 0.27 & 0.68 & 0.13 & 0.15 & 0.04 & 0.05 & 15.62 & 7.45 \\
\hline & 16 & 0.22 & 0.02 & 0.01 & 0.22 & 0.27 & 0.18 & 0.25 & 2.53 \\
\hline & 17 & 0.14 & 0.78 & 0.20 & 0.44 & 0.16 & 0.04 & 16.17 & 4.07 \\
\hline & 18 & 0.41 & 2.54 & 0.57 & 0.52 & 0.40 & 0.20 & 72.34 & 11.49 \\
\hline & 19 & 3.07 & 0.46 & 0.86 & 6.67 & 34.09 & 10.62 & 3.32 & 48.52 \\
\hline & 20 & 2.91 & 0.31 & 0.52 & 2.21 & 11.53 & 4.10 & 1.40 & 53.13 \\
\hline \multirow{2}{*}{1478} & 21 & 0.71 & 0.11 & 0.15 & 0.37 & 2.65 & 0.40 & 0.84 & 7.05 \\
\hline & 22 & 0.13 & 0.85 & 0.05 & 0.12 & 0.08 & 0.13 & 24.02 & 4.21 \\
\hline
\end{tabular}

reequilibration. Large inclusions are more extendable than small inclusions, and fluid inclusions undergoing extension have a higher $T_{\mathrm{h}}$ than the original temperature at the time of formation [47]. In other words, if inclusions have undergone extension, large inclusions are more likely to produce higher $T_{\mathrm{h}}$ values than small inclusions. Our results show that there is no correlation between the size of fluid inclusions and the corresponding $T_{\mathrm{h}}$ (Figure 5). Therefore, thermal reequilibration did not alter or damage halite crystals, which further supports the rationality and stability of the $T_{\mathrm{h}}$ data. The $T_{\mathrm{h}}$ data from middle Eocene rock salt from borehole DZK01 may accurately reflect the brine temperatures during salt formation.

5.2. Significance of Paleobrine Temperature. The temperature of the brine during the salt-forming period can be directly and quantitatively reconstructed from the $T_{\mathrm{h}}$ values of halite fluid inclusions $[15,16,48]$. In addition, previous studies on modern salt lakes and laboratory halite crystals have shown that the highest $T_{\mathrm{h}}$ values of halite fluid inclusions are approximately equal to the highest brine temperature during the halite crystallization process $[14,45,49]$. Our results show that the $T_{\mathrm{h}}$ values of the 4 salt-bearing intervals are generally high (Figure 6), with an average value of $28.3^{\circ} \mathrm{C}$ and a maximum temperature of $54.1^{\circ} \mathrm{C}$, which represent the average and high-temperature brine characteristics in the Kuqa Basin in the middle Eocene. Bougeois et al. [50] con-

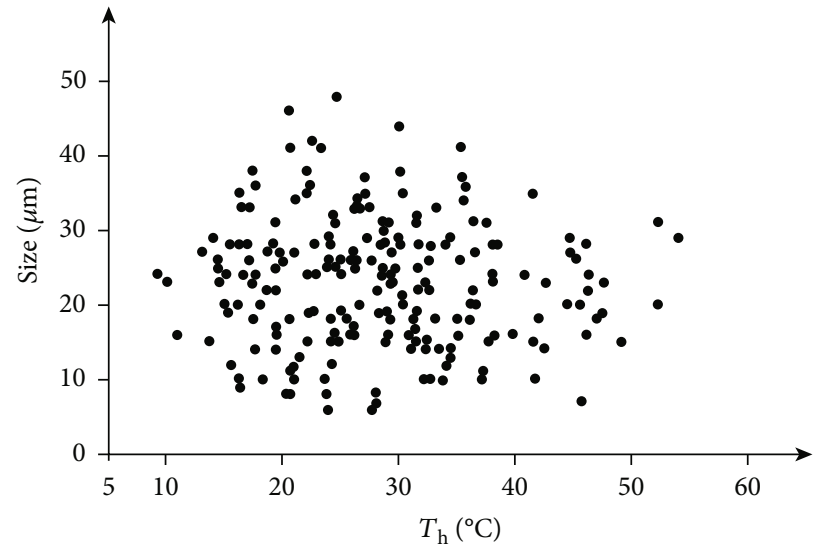

FIgure 5: Crossplot of the $T_{\mathrm{h}}$ data against the size of fluid inclusions.

ducted a study on marine oyster fossils in the southwestern part of the Tarim Basin and showed that the average sea surface temperature during the middle Eocene was approximately $27-28^{\circ} \mathrm{C}$. Therefore, the evidence supports our inference based on $T_{\mathrm{h}}$ data and indicates that our $T_{\mathrm{h}}$ data in the middle Eocene Kuqa Basin are reliable and reasonable.

Zhao et al. [17] studied halite fluid inclusions from 8 saltbearing basins in China and other countries and used the $T_{\mathrm{h}}$ 


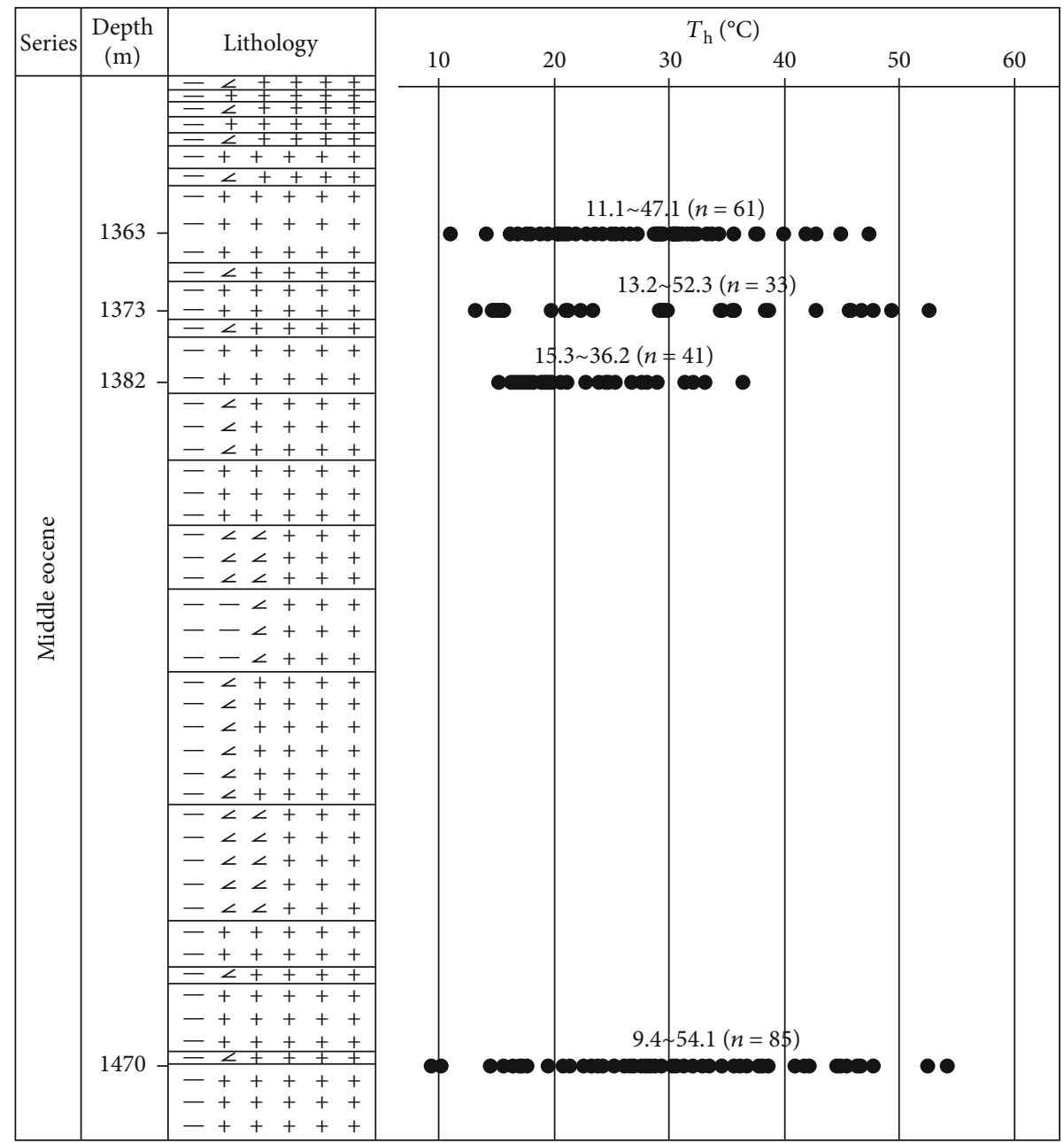

Legend
\begin{tabular}{|l}
$\begin{array}{l}-++ \\
+++\end{array}$ \\
$\begin{array}{l}-++ \\
+++\end{array}$ \\
+++ Mypsum-bearing argillaceous rock salt
\end{tabular}

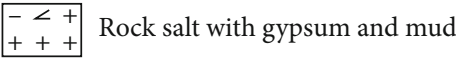

\begin{tabular}{|l|l}
$-<<$ \\
+++
\end{tabular} Mud-bearing gypsiferous rock salt

FIgURE 6: $T_{\mathrm{h}}$ data characteristics of primary fluid inclusions from middle Eocene halite in borehole DZK01, Kuqa Basin.

values to estimate the evaporation rate of ancient salt lakes, and the results showed that extremely high-temperature conditions (water and air temperatures) are conducive to rapidly concentrating salt lake brine, shortening the time interval from salt formation to potash formation, which is beneficial to the formation of potash deposits. Liu et al. [51] proposed that a hot and dry climate is a prerequisite for potash formation by ancient salt lake evaporation. The formation of many ancient and modern potash deposits is closely related to high-temperature paleobrine environments. For example, the highest paleobrine temperature of potash deposits in the Silurian Michigan Basin is $59^{\circ} \mathrm{C}$ [52], the highest paleobrine temperature of potash deposits in the Middle Cretaceous Korat Plateau is $62.1^{\circ} \mathrm{C}$ [53], and the highest paleobrine temperature of Quaternary Lop Nur potash deposits in the Tarim Basin is $58^{\circ} \mathrm{C}$ [54]. Therefore, the high-temperature conditions experienced during the middle Eocene salt-forming period in the Kuqa Basin may indicate relatively rapid evaporation rates.
Moreover, potassium minerals, such as sylvite, carnallite, and syngenite, have been discovered in this stratum [55], indicating that the salt lake brine experienced high degrees of evaporation and concentration under the high-temperature conditions required for potash formation.

\subsection{Significance of the Chemical Composition of Paleobrine.} The elements $\mathrm{K}$ and $\mathrm{Rb}$ and the elements $\mathrm{Sr}$ and $\mathrm{Ca}$ have similar chemical properties, and they often displace each other in an isomorphic manner during continuous evaporation and the concentration of salt-forming brine. In addition, $\mathrm{K}$ is positively correlated with $\mathrm{Mg}$ and $\mathrm{Br}[56,57]$. Therefore, the linear relationships between $\mathrm{K}^{+}$and $\mathrm{Mg}^{2+}, \mathrm{K}^{+}$and $\mathrm{Rb}^{+}$, $\mathrm{K}^{+}$and $\mathrm{Br}^{-}$, and $\mathrm{Ca}^{2+}$ and $\mathrm{Sr}^{2+}$ are often used to indicate the reliability of measured data $[23,58]$. The ion concentrations that we tested showed good positive correlations (Figure 7), conforming to the evaporation and concentration patterns 

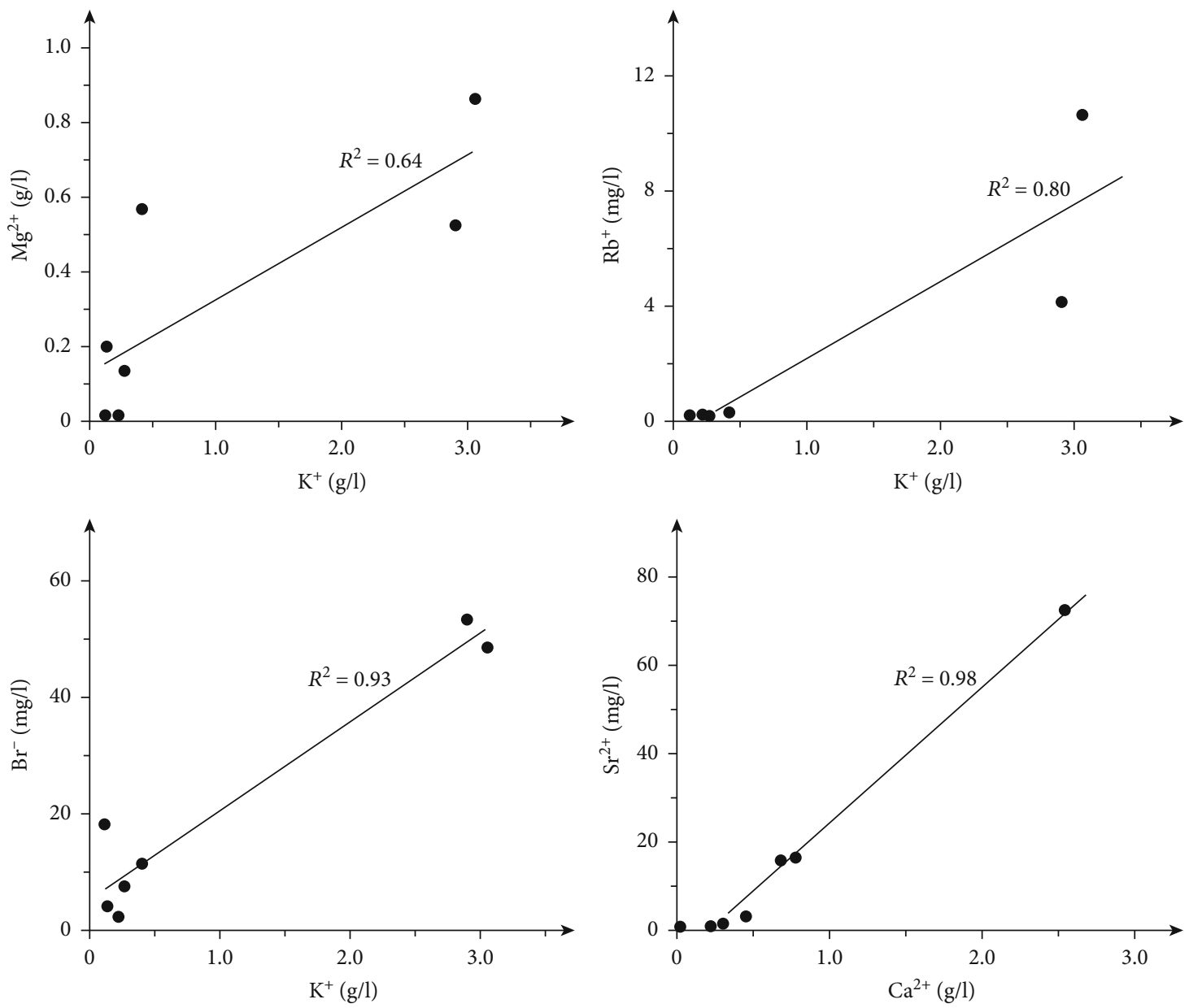

Figure 7: The relationships between $\mathrm{K}^{+}$and $\mathrm{Mg}^{2+}, \mathrm{Rb}^{+}$and $\mathrm{Br}^{-}$, and $\mathrm{Sr}^{2+}$ and $\mathrm{Ca}^{2+}$ in halite fluid inclusions from $1476 \mathrm{~m}$ in borehole $\mathrm{DZK} 01$.

of salt lake brine, indicating that our data have good reliability and validity.

The chemical compositions of halite fluid inclusions are characterized by high $\mathrm{Ca}^{2+}$ and $\mathrm{Sr}^{2+}$ concentrations, which may be due to the supply of terrestrial fresh water involved in the salinization process. Zhang et al. [12] and $\mathrm{Xu}$ et al. [59] systematically analyzed the carbon, oxygen, sulfur, and strontium isotope compositions of middle Eocene carbonate rocks and sulfate rocks and found that the provenance in the salt-forming environment was mostly a mixture of marine and continental sediments. The $\mathrm{Br}^{-}$data from that study are compared with the chemical analysis results for the rock salt from borehole DZK01 [60], and the $\mathrm{Br}^{-}$content in the latter is lower than the detection limit, whereas the $\mathrm{Br}^{-}$ content in the former is higher than the detection limit. This pattern is determined by the chemical properties of $\mathrm{Br}$ because $\mathrm{Br}$ rarely enters the crystal lattice of salt minerals but is present mainly in the form of brine.

The concentrations of other ions in the no. 19 and no. 20 fluid inclusions from the $1476 \mathrm{~m}$ halite sample are all the maximum values except for $\mathrm{Ca}^{2+}$ and $\mathrm{Sr}^{2+}$; there are two reasons for this. On the one hand, salt lake brine generally undergoes evaporative concentration and desalination caused by the mixing of external water bodies during the evolution process. At
$1476 \mathrm{~m}$, the brine evaporates and evolves to a higher concentration stage and the concentrations of $\mathrm{K}^{+}, \mathrm{Mg}^{2+}, \mathrm{Rb}^{+}$, and $\mathrm{Br}^{-}$increase accordingly. In addition, a previous work discovered potassium minerals at $1476 \mathrm{~m}$ at the bottom of the borehole, which also confirmed the high degrees of evaporation and concentration of brine. On the other hand, due to the large sample collection interval, these ion concentrations did not show a good transitional relationship, indicating that the ion concentrations of inclusion nos. 19 and 20 differ greatly from those of other inclusions. The $\mathrm{K}^{+}$concentrations in the no. 19 and no. 20 fluid inclusions reach $3.07 \mathrm{~g} / \mathrm{L}$ and $2.91 \mathrm{~g} / \mathrm{L}$, respectively, corresponding to $\mathrm{KCl}$ contents of $0.59 \%$ and $0.56 \%$, respectively. Li et al. [61], based on the "specifications for salt lakes, salt mineral exploration (DZ/T0212-2002),", systematically collected recent survey results and research data on potassium-rich brine and summarized and determined the lowest industrial grade of potassium-rich brine $(\mathrm{KCl} \geq 0.5 \%)$. It can be inferred that the evolution phase of ancient brine in the basin reached the stage of potash formation. In addition, Wu et al. [60] conducted a chemical analysis of rock salt samples from different depths in borehole DZK01 and showed that the rock salt at the bottom of the borehole has a high content of $\mathrm{K}^{+}$, with a maximum of $0.34 \%$. Xu et al. [55] studied the hydrogen and oxygen isotopes of primary fluid inclusions in halite 
from borehole DZK01 and found that the salt-bearing strata at the bottom of the borehole had experienced a high degree of evaporation and that large amounts of potassium minerals precipitated. The interval that has good potential for potassium mineral formation is inferred to have good potential for potash formation. This is consistent with the $\mathrm{K}^{+}$concentration characteristics of halite fluid inclusions studied in this paper and further shows that brine had high degrees of evaporation and concentration in the early salt-forming period and reached the potassium-forming stage.

\section{Conclusions}

(1) The $T_{\mathrm{h}}$ data of measured primary halite fluid inclusions are accurate and reasonable, and these data can quantitatively reconstruct the temperature of salt-forming brine in the Kuqa Basin in the middle Eocene. The $T_{\mathrm{h}}$ of 220 fluid inclusions ranges from 9.4 to $54.1^{\circ} \mathrm{C}$, reflecting a high-temperature brine environment that was conducive to the rapid deposition of potassium minerals

(2) The $\mathrm{KCl}$ content of salt-forming brine at the bottom of the borehole can reach up to $0.59 \%$, which is higher than the lowest industrial grade of potassium-rich brine $\mathrm{KCl}(0.5 \%)$. Combined with previous research work, these results further show that salt-forming brine had high degrees of evaporation and concentration and reached the potash-forming stage

\section{Data Availability}

The data used to support the findings of this study are available from the corresponding authors upon request.

\section{Conflicts of Interest}

The authors declare that they have no conflicts of interest.

\section{Acknowledgments}

This study was supported by the National Natural Science Foundation of China (Grant no. 41902064) and the Scientific Research Foundation for PhD, East China University of Technology (Grant no. DHBK2018029) and an independent fund from the State Key Laboratory of Nuclear Resources and Environment (Grant no. 2020Z11).

\section{References}

[1] J. K. Warren, "Evaporites through time: Tectonic, climatic and eustatic controls in marine and nonmarine deposits," Earth Science Reviews, vol. 98, no. 3-4, pp. 217-268, 2010.

[2] Q. Liu, Y. H. Chen, Y. C. Li, Q. C. Lan, H. R. Yuan, and D. L. Yan, Meso-Cenozoic terrigenous clastic rock-chemical rock salt deposits in China, Beijing Science and Technology Press, Beijing, 1987.

[3] C. L. Liu, P. C. Jiao, Z. Q. Xuan, Y. T. Cao, and X. F. Zhao, "Paleogene potash mineral advances of evaporites in Kuqa Basin,” Geological Review, vol. 59, no. 2, pp. 233-234, 2013.
[4] Y. Xu, C. L. Liu, P. C. Jiao, Y. Z. Chen, and Y. T. Cao, "Geochemical characteristics and potash formation analysis of Paleocene-Eocene evaporites in Kuqa depression of Xinjiang: a case study of borehole KL4," Acta Petrologica et Mineralogica, vol. 36, no. 5, pp. 755-764, 2017.

[5] C. L. Liu, Y. J. Zhao, X. M. Fang et al., "Plate tectonics control on the distribution and formation of the marine potash deposits," Acta Geoligca Sinica, vol. 89, no. 11, pp. 18931907, 2015.

[6] P. N. Pearson and M. R. Palmer, "Atmospheric carbon dioxide concentrations over the past 60 million years," Nature, vol. 406, no. 6797, pp. 695-699, 2000.

[7] M. Pagani, J. C. Zachos, K. H. Freeman, B. Tipple, and S. Bohaty, "Marked decline in atmospheric carbon dioxide concentrations during the Paleogene," Science, vol. 309, no. 5734, pp. 600-603, 2005.

[8] J. C. Zachos, G. R. Dickens, and R. E. Zeebe, "An early Cenozoic perspective on greenhouse warming and carbon-cycle dynamics," Nature, vol. 451, no. 7176, pp. 279-283, 2008.

[9] P. F. Sexton, R. D. Norris, P. A. Wilson et al., "Eocene global warming events driven by ventilation of oceanic dissolved organic carbon," Nature, vol. 471, no. 7338, pp. 349-352, 2011.

[10] J. X. Xu, H. Z. Ma, Y. K. Xiao et al., "Stable chlorine isotope and its research on applied geochemistry," Journal of Salt Lake Research, vol. 16, no. 1, pp. 51-59, 2008.

[11] Y. T. Cao, H. J. Yang, C. L. Liu, Q. Y. Gu, P. C. Jiao, and Y. H. Lu, "Response on sediment of evaporate in Kuqa Basin from Paleogene to Neogene period and Himalayan tectonic phase," Acta Sedimentologica Sinica, vol. 28, no. 6, pp. 1054-1065, 2010.

[12] H. Zhang, C. L. Liu, Y. T. Cao, H. W. Sun, and L. C. Wang, "A tentative discussion on the time and the way of marine regression from Tarim Bay during the Cenozoic," Acta Geoscientica Sinica, vol. 34, no. 5, pp. 577-584, 2013.

[13] S. M. Roberts and R. J. Spence, "Paleotemperatures preserved in fluid inclusions in halite," Geochimica et Cosmochimica Acta, vol. 59, no. 19, pp. 3929-3942, 1995.

[14] T. K. Lowenstein, J. Li, and C. B. Brown, "Paleotemperatures from fluid inclusions in halite: method verification and a 100,000 year paleotemperature record, Death Valley, CA," Chemical Geology, vol. 150, no. 3-4, pp. 223-245, 1998.

[15] J. J. Zambito IV and K. C. Benison, "Extremely high temperatures and paleoclimate trends recorded in Permian ephemeral lake halite," Geology, vol. 41, no. 5, pp. 587-590, 2013.

[16] H. Zhang, F. Lü, S. Mischke, M. Fan, F. Zhang, and C. Liu, "Halite fluid inclusions and the late Aptian sea surface temperatures of the Congo Basin, northern South Atlantic Ocean," Cretaceous Research, vol. 71, pp. 85-95, 2017.

[17] Y. J. Zhao, C. L. Liu, H. Zhang, Z. Q. Li, T. Ding, and M. Q. Wang, "The control of paleotemperature on potassium salt precipitation in ancient salt lakes," Acta Petrologica Sinica, vol. 31, no. 9, pp. 2751-2756, 2015.

[18] M. Q. Wang, Y. J. Zhao, C. L. Liu, and T. Ding, "Paleotemperature and sinificance of the evaporated seawater in salt-forming process of the forth member of Jialingjiang Formation in the eastern Sichuan Basin," Acta Petrologica Sinica, vol. 31, no. 9, pp. 2745-2750, 2015.

[19] T. K. Lowenstein, M. N. Timofeeff, S. T. Brennan, L. A. Hardie, and R. V. Demicco, "Oscillations in Phanerozoic seawater chemistry: evidence from fluid inclusions," Science, vol. 294, no. 5544, pp. 1086-1088, 2001. 
[20] M. G. Siemann and B. Ellendorff, "The composition of gases in fluid inclusions of late Permian (Zechstein) marine evaporites in Northern Germany," Chemical Geology, vol. 173, no. 1-3, pp. 31-44, 2001.

[21] D. I. Cendón, C. Ayora, J. J. Pueyo, C. Taberner, and M. M. Blanc-Valleron, "The chemical and hydrological evolution of the Mulhouse potash basin (France): are "marine" ancient evaporites always representative of synchronous seawater chemistry?," Chemical Geology, vol. 252, no. 3-4, pp. 109124, 2008.

[22] T. K. Lowenstein, L. A. C. Dolginko, and J. García-Veigas, "Influence of magmatic-hydrothermal activity on brine evolution in closed basins: Searles Lake, California," Geological Society of America Bulletin, vol. 128, no. 9-10, pp. 1555-1568, 2014.

[23] X. H. Sun, Y. F. Hu, C. L. Liu et al., “Argument that brine of salty lake in Sichuan Basin had reached crystallizing point of potash minerals during Triassic: evidence from chemical composition of fluid inclusions in halite," Mineral Deposits, vol. 35, no. 6, pp. 1157-1168, 2016.

[24] R. Bosboom, G. Dupontnivet, A. Grothe, H. Brinkhuis, and G. Villa, "Linking Tarim Basin sea retreat (West China) and Asian aridification in the late Eocene," Basin Research, vol. 26, no. 5, pp. 621-640, 2014.

[25] A. Yin, P. E. Rumelhart, R. Butler et al., "Tectonic history of the Altyn Tagh fault system in northern Tibet inferred from Cenozoic sedimentation," Geological Society of America Bulletin, vol. 114, no. 10, pp. 1257-1295, 2002.

[26] H. B. Zheng, R. Tada, J. T. Jia, C. Lawrence, and K. Wang, "Cenozoic sediments in the southern Tarim Basin: implications for the uplift of northern Tibet and evolution of the Taklimakan Desert," Geological Society, London, Special Publications, vol. 342, no. 1, pp. 67-78, 2010.

[27] J. M. Sun, B. Windley, Z. L. Zhang, B. H. Hu, and S. H. Li, "Diachronous seawater retreat from the southwestern margin of the Tarim Basin in the late Eocene," Journal of Asian Earth Sciences, vol. 116, pp. 222-231, 2016.

[28] B. Carrapa, P. G. De Celles, X. Wang et al., "Tectono-climatic implications of Eocene Paratethys regression in the Tajik basin of central Asia," Earth and Planetary Science Letters, vol. 424, pp. 168-178, 2015.

[29] J. M. Sun, W. G. Liu, Z. H. Liu, and B. H. Fu, "Effects of the uplift of the Tibetan Plateau and retreat of Neotethys Ocean on the stepwise aridification of mid-latitude Asian interior," Bulletin of the Chinese Academy of Sciences, vol. 26, no. 9, pp. 39-46, 2017.

[30] X. Chen, H. Chen, X. Lin et al., "Arcuate Pamir in the Paleogene? Insights from a review of stratigraphy and sedimentology of the basin fills in the foreland of NE Chinese Pamir, western Tarim Basin," Earth-Science Reviews, vol. 180, pp. 116, 2018.

[31] H. A. Abels, G. Dupont-Nivet, G. Xiao, R. Bosboom, and W. Krijgsman, "Step-wise change of Asian interior climate preceding the Eocene-Oligocene Transition (EOT)," Palaeogeography, Palaeoclimatology, Palaeoecology, vol. 299, no. 34, pp. 399-412, 2011.

[32] J. Dercourt, L. E. Ricou, and B. Vrielynck, Atlas Tethys Paleoenvironmental Maps: Expanatory Notes, Gauthiervillars, Paris, 1993.

[33] H. Z. Wang, Atlas of the paleogeography of China, China Cartographic Publishing House, Beijing, 1985.
[34] S. A. Graham, M. S. Hendrix, L. B. Wang, and A. R. Carroll, "Collisional successor basins of Western China: impact of tectonic inheritance on sand composition," Geological Society of America Bulletin, vol. 105, no. 3, pp. 323-344, 1993.

[35] L. Huafu, D. G. Howell, J. Dong et al., "Rejuvenation of the Kuqa Foreland Basin, northern flank of the Tarim Basin, Northwest China," International Geology Review, vol. 36, no. 12, pp. 1151-1158, 1994.

[36] Y. M. Zhang, G. Z. He, and Z. R. Wang, "Analysis of the tertiary salt rock system and potassium fertilizer in Kuqa Basin," Northwestern Geology, vol. 26, no. 4, pp. 44-52, 1982.

[37] M. Zheng and Z. F. Meng, "Magnetostratigraphy of tertiary system in Baicheng, Xinjiang," Acta Sedimentologica Sinica, vol. 24, no. 5, pp. 650-656, 2006.

[38] Z. H. Teng, L. P. Yue, D. F. He, X. Q. Deng, and X. W. Bian, "Magnetostratigraphic research of Cenozoic section of Kuche River area, South Xinjiang," Journal of Stratigraphy, vol. 21, no. 1, pp. 55-62, 1997.

[39] Z. Li, Q. C. Wang, D. X. Wang, and W. Lin, "Depositional record constraints on Late Cenozoic uplift of Tianshan and tectonic transformation in Kuqa Depression, West China," Acta Sedimentologica Sinica, vol. 21, no. 1, pp. 38-45, 2003.

[40] Y. T. Cao, C. L. Liu, H. J. Yang, Q. Y. Gu, P. C. Jiao, and Y. H. $\mathrm{Lu}$, "Identification and correlation of the Paleogene and Neogene evaporites sedimentary cycles in Kuqa Basin, Xinjiang," Journal of Palaeogeography, vol. 12, no. 1, pp. 31-41, 2010.

[41] Y. Xu, C. L. Liu, Y. T. Cao, and H. Zhang, "Quantitative temperature recovery from middle Eocene halite fluid inclusions in the easternmost Tethys realm," International Journal of Earth Sciences, vol. 108, no. 1, pp. 173-182, 2019.

[42] M. Y. Hu, H. L. He, X. C. Zhan, X. T. Fan, G. Wang, and Z. R. Jia, "Matrix normalization for in-situ multi-element quantitative analysis of zircon in Laser Ablation-Inductively Coupled Plasma Mass Spectrometry," Chinese Journal of Analytical Chemistry, vol. 36, no. 7, pp. 947-953, 2008.

[43] X. H. Sun, M. Y. Hu, C. L. Liu et al., "Composition determination of single fluid inclusions in salt minerals by laser ablation ICP-MS," Chinese Journal of Analytical Chemistry, vol. 41, no. 2, pp. 235-241, 2013.

[44] H. P. Longerich, S. E. Jackson, and D. Gunther, "Inter-laboratory note. Laser ablation inductively coupled plasma mass spectrometric transient signal data acquisition and analyte concentration calculation," Journal of Analytical Atomic Spectrometry, vol. 11, no. 9, pp. 899-904, 1996.

[45] K. C. Benison and R. H. Goldstein, "Permian paleoclimate data from fluid inclusions in halite," Chemical Geology, vol. 154, no. 1-4, pp. 113-132, 1999.

[46] R. H. Goldstein and T. J. Reynolds, "Systematics of fluid inclusions in diagenetic minerals," Society for Sedimentary Geology, vol. 26, no. 1, pp. 23-47, 1994.

[47] E. Roedder, "The fluids in salt," American Mineralogist, vol. 69, no. 5, pp. 413-439, 1984.

[48] Y.-j. Zhao, H. Zhang, C.-1. Liu, B.-k. Liu, L.-c. Ma, and L.c. Wang, "Late Eocene to early Oligocene quantitative paleotemperature record: evidence from continental halite fluid inclusions," Scientific Reports, vol. 4, article 5776, 2014.

[49] X.-h. Sun, Y.-j. Zhao, C.-l. Liu, P.-c. Jiao, H. Zhang, and C.h. $\mathrm{Wu}$, "Paleoclimatic information recorded in fluid inclusions in halites from Lop Nur, Western China," Scientific Reports, vol. 7, no. 1, article 16411, 2017. 
[50] L. Bougeois, M. de Rafélis, G. J. Reichart, L. J. de Nooijer, F. Nicollin, and G. Dupont-Nivet, "A high resolution study of trace elements and stable isotopes in oyster shells to estimate Central Asian Middle Eocene seasonality," Chemical Geology, vol. 363, pp. 200-212, 2014.

[51] C. L. Liu, Z. Q. Xuan, Y. T. Cao et al., "Research on potash exploration at China land mass-potash alteration and pattern of eastern Tethys Ocean, China," Geology of Chemical Minerals, vol. 37, no. 4, pp. 193-197, 2015.

[52] A. B. Losey and K. C. Benison, "Silurian paleoclimate data from fluid inclusions in the Salina Group halite Michigan Basin," Carbonates Evaporites, vol. 15, pp. 28-36, 2000.

[53] H. Zhang, C. Liu, Y. Zhao, S. Mischke, X. Fang, and T. Ding, "Quantitative temperature records of mid Cretaceous hothouse: evidence from halite fluid inclusions," Palaeogeography, Palaeoclimatology, Palaeoecology, vol. 437, pp. 33-41, 2015.

[54] C. L. Liu, Y. Z. Chen, W. S. Chen, P. C. Jiao, M. L. Wang, and S. D. Li, "Studies of fluid inclusions in glauberite of middleupper Pleistocene strata and their paleoclimatic significance in Lop Nur salty lake, Xinjiang, NW China," Acta Mineralogica Sinica, vol. 26, no. 1, pp. 93-98, 2006.

[55] Y. Xu, Y. T. Cao, C. L. Liu, and P. C. Jiao, "Provenance and degree of evaporation and concentration of Eocene salt lake in the Kuqa Basin," Acta Geologica Sinica, vol. 92, no. 8, pp. 1617-1629, 2018.

[56] P. D. Deckker, A. R. Chivas, J. M. G. Shelley, and T. Torgersen, "Ostracod shell chemistry: a new palaeoenvironmental indicator applied to a regressive/transgressive record from the gulf of Carpentaria, Australia," Palaeogeography Palaeoclimatology Palaeoecology, vol. 66, no. 3-4, pp. 231-241, 1988.

[57] H. T. You, R. H. Cheng, and C. L. Liu, "Review of Paleosalinity recovering methods," World Geology, vol. 21, no. 2, pp. 111$117,2002$.

[58] L. Shen, C. Liu, L. Wang, Y. Hu, M. Hu, and Y. Feng, "Degree of brine evaporation and origin of the Mengyejing potash deposit: evidence from fluid inclusions in halite," Acta Geologica Sinica - English Edition, vol. 91, no. 1, pp. 175-185, 2017.

[59] Y. Xu, Y. T. Cao, C. L. Liu, H. Zhang, and X. Nie, “The history of transgressions during the Late Paleocene-Early Eocene in the Kuqa Depression, Tarim Basin: constraints from C-O-SSr isotopic geochemistry," Minerals, vol. 10, no. 9, p. 834, 2020.

[60] K. Wu, C. L. Liu, P. C. Jiao et al., "Geochemical characteristics and ore-prospecting indicators of salt-bearing series in No.1 exploratory drill hole of Kuqa Basin, Xinjiang," Mineral Deposits, vol. 33, no. 5, pp. 1011-1019, 2014.

[61] B. Y. Li, X. L. Deng, F. Wang et al., “Types, exploration techniques and suggested industrial indexes of deep-seated potassium-rich brine," Geology and Exploration, vol. 55, no. 6, pp. 1426-1435, 2019. 